\title{
Cyst Formation Following Radiosurgery for AVMs: Report of 3 Cases
}

\author{
Q. Al Hinai, D. Tampieri, L. Souhami, A. Sadikot, D. Sinclair, R. Leblanc
}

\begin{abstract}
Background: Stereotactically-focused radiosurgery (SRS) for the treatment of arteriovenous malformations (AVM) has been in widespread use for over two decades. Over this timeframe the indications for treatment, standardization of radiation dosage, and the results expected from treatment have been elaborated. Less well known are the long-term complications associated with SRS. We report three patients who had SRS for the treatment of AVM who developed a cyst at the site of treatment as a late complication. Methods: From 201 patients treated by SRS for an AVM, three developed a cyst at the treatment site. Their clinical presentation, the characteristics of the AVMs and the treatment were reviewed, as well as similar cases gleaned from the literature. Results: Three women, aged 28-43 years, had an AVM treated by: craniotomy and clipping of arterial feeders followed by SRS, by craniotomy for resection followed by SRS or by endovascular embolization and SRS. The patients did well following treatment but two of them developed a symptomatic and the other an asymptomatic cyst at the treatment site 3-19 years later. The symptomatic patients underwent marsupialization of the cyst and the other is under observation. Conclusion: Stereotactic radiosurgery is an established and safe treatment for patients with AVMs. Delayed cyst formation can occur many years after treatment and long term follow-up is indicated in patients whose AVM has been treated with SRS.
\end{abstract}

RÉSUMÉ: Formation d'un kyste suite au traitement d'une MAV par radiochirurgie : 3 observations. Contexte : La radiochirurgie stéréotaxique (RCS) pour traiter les malformations artérioveineuses (MAV) a été d'usage courant pendant une vingtaine d'années. Ceci a permis de préciser les indications de traitement, la standardisation de la dose de radiation et les résultats escomptés du traitement. Ce qui est moins bien connu ce sont les complications à long terme de la RCS. Nous rapportons 3 observations de patients, traités par RCS pour une MAV, qui ont présenté un kyste à la région traitée comme complication tardive du traitement. Méthode : Trois patients parmi les 201 patients traités par RCS pour une MAV ont présenté un kyste à la région traitée. Nous avons révisé les manifestations cliniques, les caractéristiques des MAVs et leur traitement ainsi que les observations similaires rapportées dans la littérature. Résultats : Trois femmes âgées de 28 à 43 ans ont été traitées soit par craniotomie et mise en place d'un clip sur les artères nourricières et RCS, par craniotomie pour la résection de la MAV suivie de RCS ou embolisation endovasculaire et RCS. Le traitement a été un succès, mais toutes les trois ont présentées un kyste à l'endroit où le traitement avait été administré, de 3 à 19 ans plus tard. Le kyste était asymptomatique chez l'une et symptomatique chez les deux autres. Chez ces dernières, on a procédé à une marsupialisation du kyste et la troisième demeure simplement sous observation. Conclusion : La radiochirurgie stéréotaxique est un traitement sûr et bien établi des MAVs. Une formation kystique tardive peut survenir plusieurs années après le traitement et un suivi à long terme est indiqué chez les patients dont la MAV a été traitée par RCS.

Can. J. Neurol. Sci. 2011; 38: 734-740

Stereotactic Radiosurgery (SRS) is a recognized treatment in the management of cerebral arteriovenous malformations (AVMs). Stereotactic Radiosurgery can be performed by a gamma knife, by a linear accelerator system, or by a particle beam system and is characterized by the accurate delivery of high dose, focused irradiation to stereotactically defined intracranial targets in such way that the dose fall-off outside the targeted volume is very sharp. Delayed radiation-induced complications from radiosurgery for AVMs can occur regardless of the system used. Most radiation-induced complications will manifest symptoms or signs within three years of radiosurgery ${ }^{1-8}$. Radiation-induced complications presenting beyond three years are less well understood. We report three cases of delayed cyst formation occurring 3,12 and 19 years post radiosurgery for an AVM.

\section{Materials AND Methods}

Between April 1986 and December 2009, 201 cerebral AVMs were treated by linear accelerator-based SRS at the Montreal
General Hospital, McGill University. Prior to SRS, all patients were assessed by a multidisciplinary team consisting of members from neurosurgery, neuroradiology and radiation oncology. Three patients developed delayed cyst formation suspected of being related to their earlier treatment. These cases are reviewed below. We reviewed the published literature on this subject from 1950 to 2010 on Google, PUBMED and Ovid MEDLINE $($ using "AVM", "stereotactic radiosurgery”,

From the Department of Neurosurgery (QAH, AS, DS, RL), Department of Diagnostic and Interventional Neuroradiology (DT), Montreal Neurological Hospital \& Institute, Department of Radiation Oncology (LS), McGill University Health Centre, Montreal, Quebec, Canada.

ReCEIVEd February 14, 2011. Final Revisions Submitted April 20, 2011. Correspondence to: Richard Leblanc, Department of Neurosurgery, Montreal Neurological Institute and Hospital, McGill University Health Centre, 3801 University Street, Montreal, Quebec, H3A 2B4, Canada. 
"radiation", "cyst formation" "cyst" and "complications" as indicators.

\section{Results}

\section{Case reports}

Case \#1: A 37-year-old female with an uneventful past medical history presented with ataxia. Computed tomography (CT) (not shown) and digital subtraction angiography (DSA) showed a vermian AVM fed by the left posterior cerebral artery and the superior cerebellar artery along with an incidental left para-ophthalmic artery aneurysm (Figure 1). The AVM dimensions were $2.2 \times 1.0 \times 3.0 \mathrm{~cm}$. The aneurysm was causing no symptoms so it was observed. In May 1992, she underwent embolization of the AVM. In June 1992, a suboccipital craniectomy with partial resection of the AVM was performed. The postoperative course was uneventful. In September 1992, SRS was given for the residual vermian AVM. A single dose of 25 Gy was prescribed to the $90 \%$ isodose surface using a single isocenter. A $2.0 \mathrm{~cm}$ cone was used to treat her lesion. There was no bleeding post-SRS. Post-treatment angiography showed complete obliteration of the nidus. Twelve years later she was diagnosed with intracranial hypertension. Computed tomography (Figure $2 \mathrm{a}$ ) demonstrated the presence of a cyst at the previous treatment site compressing the quadrigeminal plate and displacing the fourth ventricle. Marsupialization of the cyst was performed through a reopening of the previous suboccipital craniectomy, and produced full resolution of her symptoms. A post-operative CT scan (Figure 2b) showed satisfactory evacuation of the cyst and decompression of posterior fossa. On follow-up, six years after the surgical procedure, the patient remains well and has no features of intracranial hypertension.

Case \#2: A 43-year-old female presented with seizures and a visual field deficit. Digital subtraction angiography (DSA) (Figure 3a \& 3b) and magnetic resonance imaging (MRI)(Figure

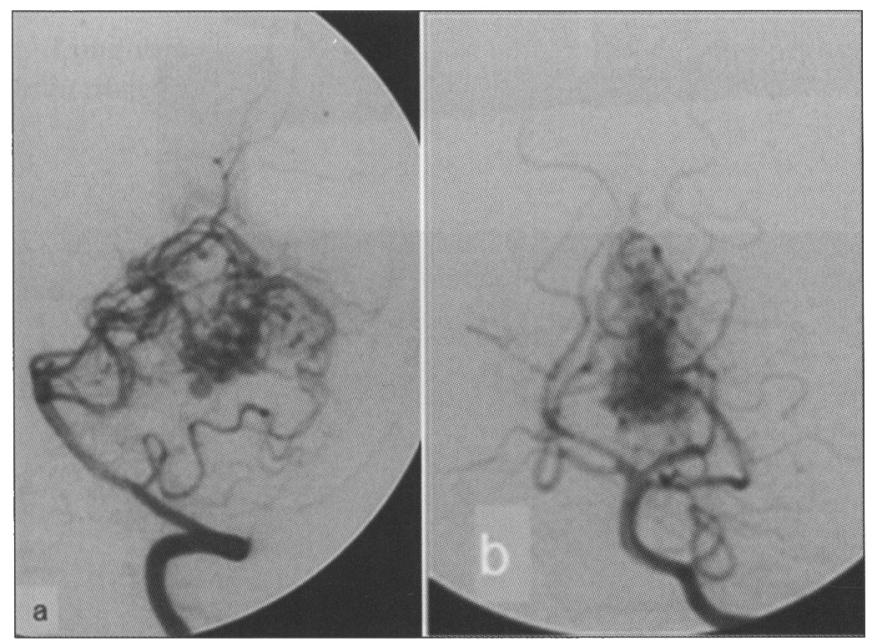

Figure 1: Case \#1 - DSA of lateral (a) and anteroposterior (b) left VA (Vertebral Artery) injection shows presence of AVM supplied by left posterior cerebral artery (PCA) and superior cerebellar artery $(S C A)$. 3d) showed the presence of a right parieto-occipital AVM fed by the right posterior cerebral artery with both deep and superficial venous drainage. The superficial drainage was to the right transverse sinus. The AVM dimensions were $3.8 \times 3.1 \times 3.9 \mathrm{~cm}$. She had three sessions of embolization and, in 2003, she underwent SRS. A single dose of $18 \mathrm{~Gy}$ was delivered to the $80 \%$ isodose surface through a single isocenter with a $3.0 \mathrm{~cm}$ cone (Figure 3c: the image of the treatment plan). There was no bleeding post-SRS. Post-treatment angiography showed $95 \%$ obliteration rate of the nidus. Three years after SRS a follow-up MRI showed the presence of a right parieto-occipital cyst (Figure $3 \mathrm{e}$ ). She was asymptomatic and has been managed conservatively. At follow-up and four years after the appearance of the cyst, she has no features of high intracranial pressure and has no visual field defects.

Case \#3: A 28-year-old female presented with a seizure. Computed tomography (Figure $4 \mathrm{a}$ ) and DSA (images are not available) showed the presence of a right frontal AVM involving the supplementary motor cortex and possibly the motor strip. The AVM was supplied mainly by the anterior cerebral artery with branches from the middle cerebral artery. The venous drainage was via short venous branches to the superior sagittal sinus. The AVM dimensions were $1.07 \times 1.42 \times 0.7 \mathrm{~cm}$. The patient underwent a fronto-parietal craniotomy under local anesthesia, cortical mapping, and clipping of the major cortical arteries supplying the malformation under fluorescein angiography control ${ }^{9}$. She had a mild post-operative left lower extremity monoplegia that improved over time and two years after surgery she underwent SRS to the AVM. This was delivered as a single dose of $14 \mathrm{~Gy}$ to the $80 \%$ isodose surface using a 1.75 $\mathrm{cm}$ cone to a single isocenter. The conformity index was 1.9. Post-treatment angiography showed complete obliteration of the nidus. She remained well until she experienced a worsening of her seizure disorder 13 years after radiosurgery. A computed tomography scan then demonstrated the presence of a cyst at the
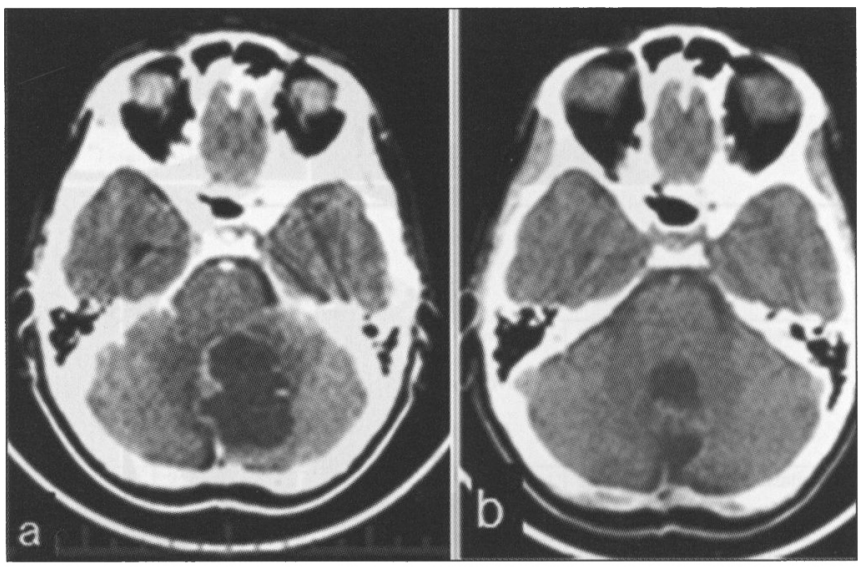

Figure 2: Case \#I - (a) Axial CT scan showing a posterior fossa cyst causing significant mass effect on the 4th ventricle and quadrigeminal cistern. (b) Post-marsupialization axial CT scan showing excellent decompression of the 4th ventricle. 

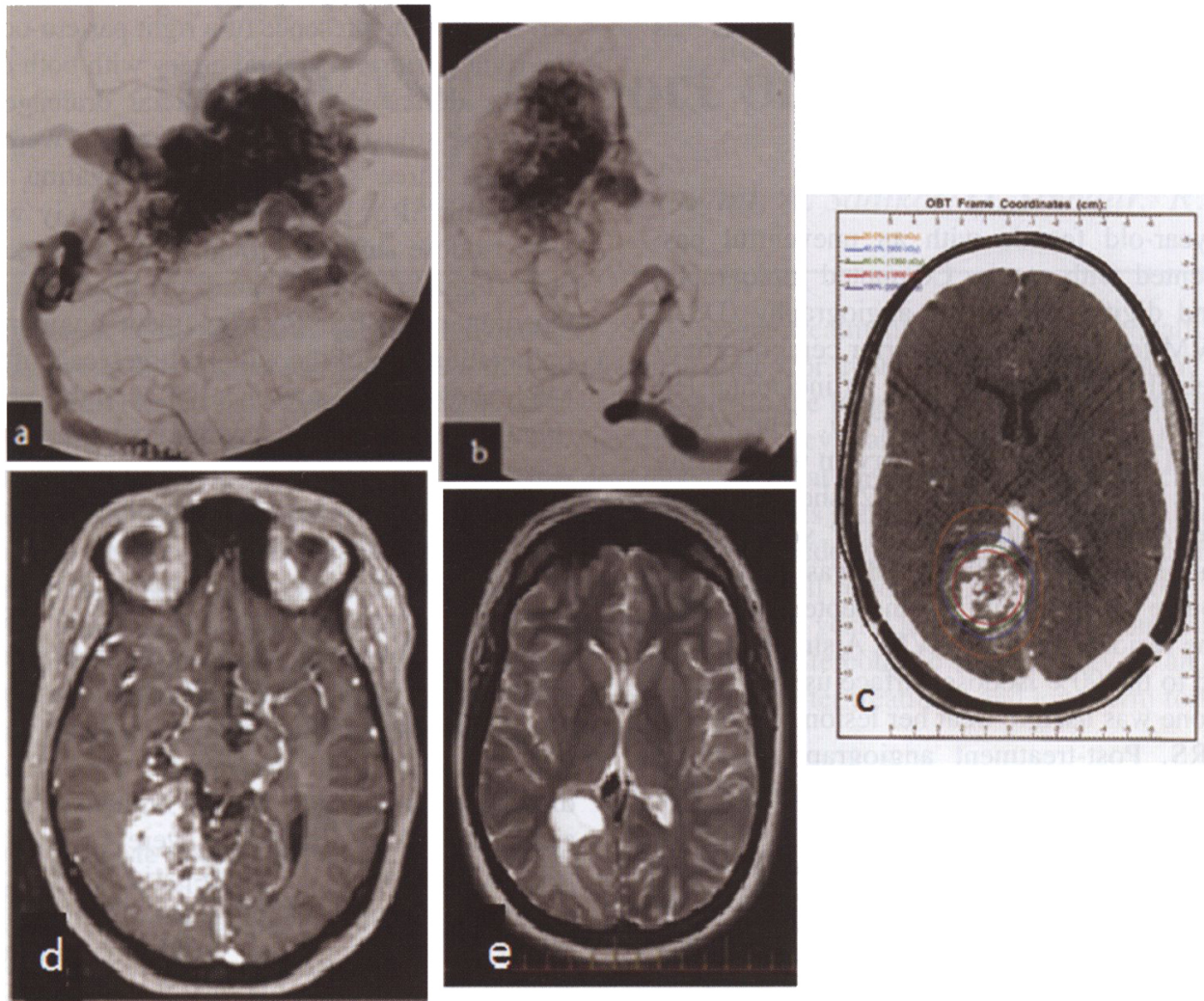

Figure 3: Case \#2 - DSA of lateral (a) and AP (b) vertebral artery injections showing a right parieto-occipital AVM fed by the right posterior cerebral artery with both deep and superficial venous drainage. The superficial drainage was mainly into the right transverse sinus. (c) The image of the treatment plan. (d) Axial TI MRI with gadolinium showing the right parieto-occipital AVM. (e) Axial T2 MR Image showing the hyperintense right parieto-occipital cyst.

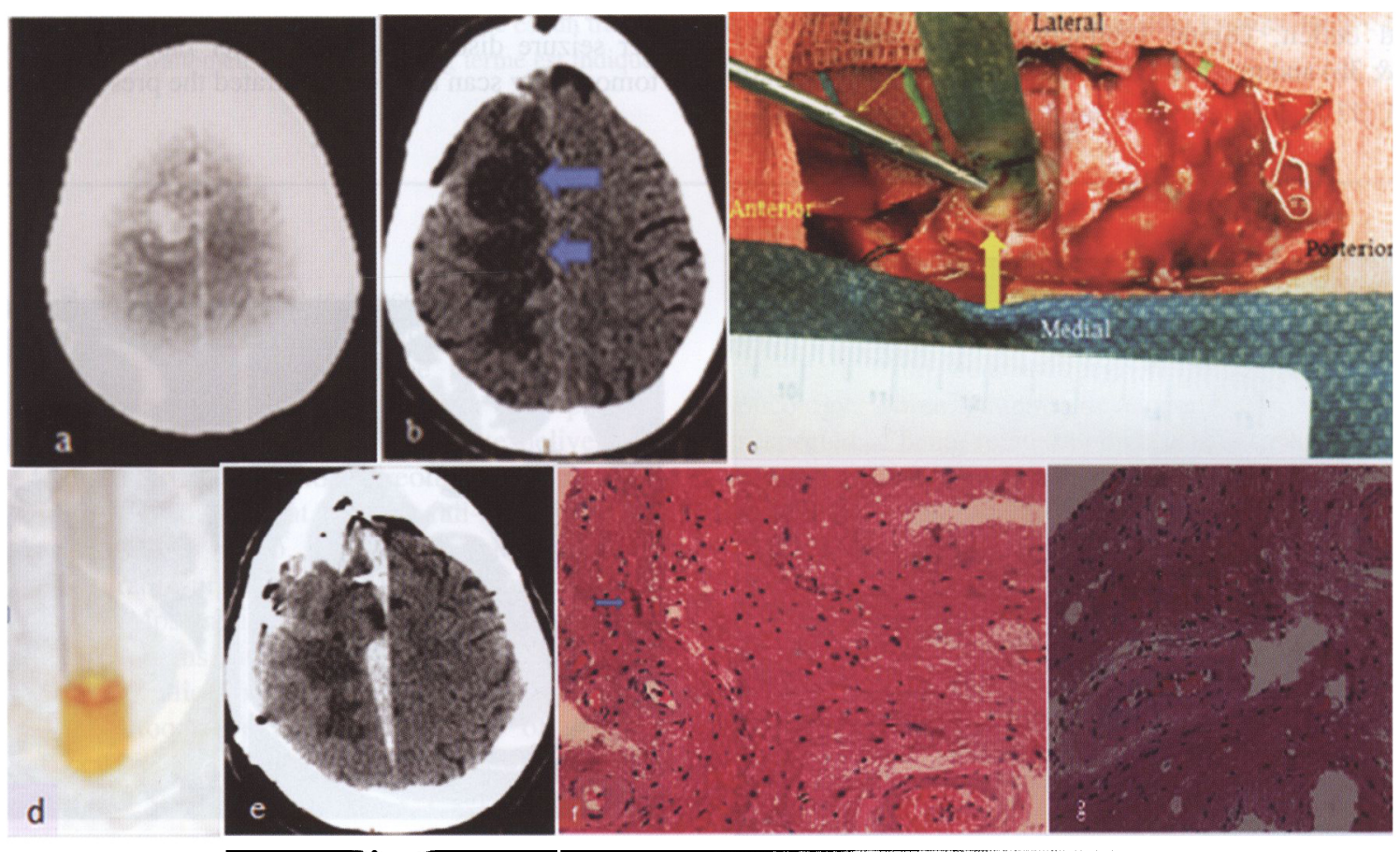

Figure 4: Case \#3 - (a) CT scan showing the right frontal AVM. (b) More recent CT scan with contrast showing the 2 cysts (arrows) with hypodense centres. (c) An intraoperative photograph shows the superficially located cyst opening (large arrow). A suction device is in the operative field (small arrow). (d) An intraoperative photograph shows the xanthochromia of the cyst fluid. (e) Post-operative CT shows disappearance of the cysts but presence of an interhemispheric subdural hematoma. $(f)$ A pathological slide shows the eosinophilic elongated Rosenthal fibre (arrow) and gliosis. ( $g$ ) A micrograph shows blood vessels with hyalinized walls. 
site of the previous treatment (Figure 4b). Her seizure disorder was managed medically and, as she remained otherwise asymptomatic, expectant management was instituted. Upon follow-up two decades after her initial presentation, she had developed a mild left hemiplegia worse in the lower extremity. She also had been experiencing daily left upper extremity focal motor seizures which had been present for many years. Repeat CT scanning showed enlargement of the cyst. She underwent a reopening of the craniotomy for cysto-subarachnoid drainage 22 years after her SRS. The procedure was carried out using neuronavigation and cortical stimulation. There were adhesions between the dura and the bone flap, the elevation of which caused a small right frontal intraparenchymal hemorrhage (which was evacuated) and an interhemispheric subdural hematoma (partially evacuated intraoperatively and managed thereafter conservatively) (Figure 4e). There were multiple yellow fluid-containing cysts (Figure 4c) which were interconnected but had a superficial component which was fenestrated to the subarachnoid space. The cyst fluid was xanthochromic (Figure 4d) and had elevated protein level of $37.38 \mathrm{~g} / \mathrm{L}$ (normal: $0.20-0.50 \mathrm{~g} / \mathrm{L}$ ). Histopathological examination revealed the presence of gliosis and Rosenthal fibres, (Figure 4f) and blood vessels with hyalinized walls (Figure $4 \mathrm{~g}$ ) with no evidence of necrosis. Postoperatively, she manifested a temporary left hemiplegia which improved over the following two weeks. At follow-up six months after the cyst drainage, her daily seizures have disappeared and she has power $4 / 5$ in the left upper and lower extremities.

The clinico-demographic and management features of the three patients are summarized in Table 1 .

\section{LITERATURE REVIEW}

The results of the literature search with regard to the frequency of cyst formation after SRS for a cerebral AVM, the patients' presentations, their management and outcomes following treatment are summarized in Table 2.

\section{Discussion}

\section{Complications of radiosurgery}

Long-term complications of SRS include necrosis, hemorrhage, cyst formation, increased seizure frequency, and arterial stenosis ${ }^{23,24}$. These complications may occur in 3.2 to $19.8 \%$ of patients undergoing treatment for $\mathrm{AVMs}^{25}$. One of the rarer complications of SRS for AVMs is delayed cyst formation. Most estimates of the incidence of cyst formation from the literature range between $0.2 \%$ and $1.6 \% 18,26$. However, Yamamoto et $\mathrm{al}^{26}$ and Nakamura ${ }^{27}$ reported a higher incidence in their series ranging from $2.8 \%$ to $7.9 \%$ (Table 3 ).

The true incidence of cyst formation from radiosurgery is difficult to establish and may be underestimated for two main reasons: first, such events may occur many years after radiosurgery and patients may have been therefore lost to follow-up; and, secondly, most patients do not undergo further imaging studies once angiography has documented a complete AVM obliteration.

The incidence of cyst formation in our patients is of the order of $1.5 \%$. Literature estimates on the incidence of delayed cyst formation is shown in Table 3.

\section{CYST FORMATION}

The mechanism of cyst formation following SRS for the treatment of a cerebral AVM is unknown and subject to controversy. One theory ascribes cyst formation to degeneration of tissue at the site of a previous intra-cerebral hematoma ${ }^{25}$. This was not the case, however, in our patients, none of whom had a cerebral hemorrhage. Furthermore, other authors have identified cysts that developed at a distance from a previous hematoma. Thus, this causative mechanism appears unlikely, at least in the majority of cases ${ }^{14}$.

The radiation-related breakdown of the blood-brain barrier post-SRS has also been hypothesized as a possible mechanism for the cyst formation ${ }^{12,14,26,28}$. Blood vessels exposed to a high dose of radiation may develop increased permeability, thus permitting fluid to be released from the vasculature into the parenchyma. This breakdown of the blood-brain barrier, combined with high blood flow in the region of the AVM, may cause accumulation of an exudative fluid and subsequent cyst formation $^{18}$.

The dose delivered and the volume irradiated in SRS influences the development of treatment-related complications. However, it is unclear whether a causal relationship exists between the dose delivered and delayed cyst formation in the

Table 1: The demographic, clinical and management features of the 3 patients

\begin{tabular}{|c|c|c|c|c|c|c|c|c|c|c|c|c|c|}
\hline Patient & $\overline{\text { Age/sex }}$ & $\begin{array}{l}\text { Initial } \\
\text { presentation }\end{array}$ & AVM site & $\begin{array}{l}\text { AVM } \\
\text { volume } \\
\left(\mathrm{cm}^{3}\right)\end{array}$ & $\begin{array}{l}\text { Spetzler- } \\
\text { Martin } \\
\text { grade }\end{array}$ & $\begin{array}{l}\text { AVM } \\
\text { Management }\end{array}$ & $\begin{array}{l}\text { Obliteration } \\
\text { rate of } \\
\text { AVM nidus }\end{array}$ & $\begin{array}{l}\text { Isodose } \\
\text { surface } \\
(\%)\end{array}$ & $\begin{array}{l}\text { Radiation } \\
\text { dose(Gy) }\end{array}$ & $\begin{array}{l}\text { Later clinical } \\
\text { presentation }\end{array}$ & $\begin{array}{l}\text { Time to } \\
\text { cyst } \\
\text { discovery } \\
\text { (years) }\end{array}$ & $\begin{array}{l}\text { Cyst } \\
\text { volume } \\
\left(\mathrm{cm}^{3}\right)\end{array}$ & Cyst Management \\
\hline 1 & $37 /$ Female & Ataxia & Vermis & 3.3 & 1 & $\begin{array}{l}\text { Embolization, } \\
\text { Surgery, SRS }\end{array}$ & $\begin{array}{l}\text { Complete } \\
\text { obliteration }\end{array}$ & 90 & 25 & $\begin{array}{l}\text { Intracranial } \\
\text { hypertension }\end{array}$ & 12 & 24.3 & Marsupialization \\
\hline 2 & 43/Female & $\begin{array}{l}\text { Seizure \& } \\
\text { neurodeficit }\end{array}$ & Right PO & 22.9 & 4 & $\begin{array}{l}\text { Embolization, } \\
\text { SRS }\end{array}$ & $95 \%$ & 80 & 18 & Asymptomatic & 3 & 6.8 & Conservative \\
\hline 3 & 28 Female & Seizure & $\begin{array}{l}\text { Right } \\
\text { Frontal }\end{array}$ & 0.5 & 2 & Surgery, SRS & $\begin{array}{l}\text { Complete } \\
\text { obliteration }\end{array}$ & 80 & 14 & $\begin{array}{l}\text { Seizures and } \\
\text { hemiparesis }\end{array}$ & 19 & 9.8 & Marsupialization \\
\hline
\end{tabular}

AVM:Arteriovenous Malformation, PO:Parieto-Occipital, SRS:Stereotactic RadioSurgery 
Table 2: Characteristics of patients reported in the literature to have a cyst formation following SRS of AVM

\begin{tabular}{|c|c|c|c|c|c|c|c|c|c|c|c|c|}
\hline No & Series & $\mathrm{C} / \mathrm{T}$ & $\mathrm{A} / \mathbf{S}$ & ic/p & $\begin{array}{l}\text { AVM site/nidus } \\
\text { volume }\end{array}$ & $\begin{array}{c}\text { SRSx } \\
\text { mode/dose }\end{array}$ & c/p of cyst & $\begin{array}{c}\begin{array}{c}\text { Delay of } \\
\text { cyst } \\
\text { formation }\end{array} \\
\end{array}$ & $\begin{array}{c}\text { Cyst } \\
\text { volume }\end{array}$ & Cyst Mx & Pathology & Outcome \\
\hline 1 & $\begin{array}{l}\text { Forster }^{16} \\
1995\end{array}$ & $3 / 1400$ & - & - & - & - & Asym & - & - & $\begin{array}{l}2: \text { Obs } \\
1: S x\end{array}$ & - & - \\
\hline 2 & $\begin{array}{l}\text { Lindquist", } \\
1995\end{array}$ & $3 \%$ & - & - & - & 3 & Asym & - & - & - & - & - \\
\hline 3 & $\begin{array}{l}\text { Yamamoto } \\
12, \\
1996\end{array}$ & $3 / 38$ & $25 / \mathrm{F}$ & Hge & $\begin{array}{l}\text { Lt parietal/ } \\
13.4 \mathrm{~cm}^{3}\end{array}$ & $\begin{array}{l}\text { Gamma } \\
\text { knife:central } \\
\text { dose } 50 \text { Gy } \\
50 \% \text { ID } \\
\text { volume }\end{array}$ & $\begin{array}{l}1: s z \\
1: \text { deficit }\end{array}$ & $9 y$ & $3.7 \mathrm{~cm}^{3}$ & $\begin{array}{l}\text { 2:Obs } \\
\text { 1:cyst resection }\end{array}$ & $\begin{array}{l}\text { Gliosis, vessels in various } \\
\text { stages of obliteration \& } \\
\text { oedema within cyst wall }\end{array}$ & Good \\
\hline 4 & $\begin{array}{l}\text { Tanaka }^{13}, \\
1997\end{array}$ & $2 / 400$ & $18.5 / \mathrm{M}$ & - & $\begin{array}{l}\text { Lt frontal } \\
\text { \&Thalamus/- }\end{array}$ & Gamma knife/ & - & $2 y$ & - & $\begin{array}{l}\text { Aspiration \& Ommaya } \\
\text { reservoir }\end{array}$ & Gliosis & - \\
\hline 5 & $\begin{array}{l}\text { Kihlstrom }{ }^{14} \\
1997\end{array}$ & $5 / 1600$ & $29 /$ & $\begin{array}{l}\text { 4:Hge } \\
1: \mathrm{sz}\end{array}$ & $\begin{array}{l}\text { Supra \& } \\
\text { infratentorial/- }\end{array}$ & $\begin{array}{l}\text { Gamma } \\
\text { knife- }\end{array}$ & Asym & $12.4 y$ & $\begin{array}{l}1-2 \mathrm{~cm}(\mathrm{no} \\
\text { vol) }\end{array}$ & - & - & - \\
\hline 6 & $\begin{array}{l}\text { Radanowicz- } \\
\text { Hartmann }{ }^{13} \\
1998\end{array}$ & $1 /-$ & $16 \%-$ & Hge & $\begin{array}{l}\text { Quadrigeminal } \\
\text { plate } / 1.5 \mathrm{~cm}^{3}\end{array}$ & $\begin{array}{l}\text { Gamma } \\
\text { knife:central } \\
\text { dose ?Gy, } \\
\text { marginai dose } \\
\text { 21Gy@70\% } \\
\text { volume }\end{array}$ & $\begin{array}{l}\text { High ICP } \\
\text { secondary to } \\
\text { HCP }\end{array}$ & $6.5 y$ & - & Cyst resection & - & Excellent:asym \\
\hline 7 & $\begin{array}{l}\mathrm{Kim}^{1 \mathrm{ki}} \\
1999\end{array}$ & $1 / 82$ & $17 \mathrm{M}$ & Hge & Lt parietal $/ 15 \mathrm{~cm}^{3}$ & $\begin{array}{l}\text { Gamma knife } \\
\text { max dose } \\
50 G y, \\
\text { marginal } \\
\text { dose25Gy, } \\
50 \% \text { ID }\end{array}$ & Hemiparesis & - & $70 \mathrm{~cm}^{3}$ & $\begin{array}{l}\text { Stereotactic aspir \& } \\
\text { Ommaya reservoir }\end{array}$ & - & $\begin{array}{c}\text { Symptoms } \\
\text { improved \& cyst disappeared }\end{array}$ \\
\hline 8 & $\begin{array}{l}\text { Flickinger", } \\
1999\end{array}$ & $5 / 1255$ & $28 / \mathrm{M}$ & - & $\begin{array}{l}\text { Supra \& } \\
\text { infratentorial/- }\end{array}$ & $\begin{array}{l}\text { Gamrna } \\
\text { knife- dose } \\
27.5 \mathrm{~Gy}\end{array}$ & $\begin{array}{l}\text { 2:asym } \\
\text { 3:sz/deficit }\end{array}$ & 81 months & - & $\begin{array}{l}\text { 1:refused Sx } \\
\text { 1:exc } \\
2: 0 b s \\
1: \text { cyst resolved } \\
\text { completely }\end{array}$ & - & Resolution of symtoms \\
\hline 9 & $\begin{array}{l}\text { Pollock }{ }^{18} \text {, } \\
2001\end{array}$ & $6 /-$ & $24 /-$ & $\begin{array}{l}\mathrm{H} / \mathrm{A}, \\
\text { sz \& } \\
\text { hge }\end{array}$ & Supratentorial/ & $\begin{array}{l}\text { 2:LINAC } \\
\text { 4:Gamma } \\
\text { knife }\end{array}$ & $\begin{array}{l}\text { 3:asym but } \\
\text { increase cyst } \\
\text { size } \\
\text { 3:monoparesis } \\
\text {, sz }\end{array}$ & 48 months & $5.8 \mathrm{~cm}^{3}$ & $\begin{array}{l}\text { 3:aspir } \\
\text { 2:CPS } \\
\text { 1:cyst excision }\end{array}$ & - & No complications \\
\hline 10 & $\begin{array}{l}\text { Pan', } \\
2005\end{array}$ & $20 / 1203$ & $31 / 10: 10$ & - & $\begin{array}{l}\text { Supra \& } \\
\text { infratentorial }\end{array}$ & Gamma knife & $\begin{array}{l}\text { 14:asym } \\
\text { 6:sz/deficit }\end{array}$ & $\begin{array}{l}98.2 \\
\text { months }\end{array}$ & $6.8 \mathrm{~cm}^{3}$ & $\begin{array}{l}\text { 3:obs } \\
\text { 2:exc } \\
\text { 1:CPS }\end{array}$ & & - \\
\hline 11 & $\begin{array}{l}\text { [zawa }^{20} \\
2007\end{array}$ & $12 /-$ & $31.8 / \mathrm{M}$ & $\mathrm{sz}, \mathrm{H} / \mathrm{A}$ & loabar $/ 8.3 \mathrm{~cm}^{3}$ & Gamma knife $/ 22 \mathrm{~Gy}$ & $\begin{array}{l}\text { 10:sz,H/A, } \\
\text { 2:asym }\end{array}$ & $6.7 y$ & NA & $\begin{array}{l}\text { 4:obs } \\
6: c y s t \text { exc } \\
2: \text { CPS }\end{array}$ & $\mathrm{NA}$ & good condition \\
\hline 12 & $\begin{array}{l}\text { Wolak" }^{21} \\
2007\end{array}$ & $1 /-$ & $22 / F$ & $\mathrm{H} / \mathrm{A}$ & R occip pole/NA & Gamma knife /18Gy & $\mathrm{H} / \mathrm{A}$ & 63 month & $\mathrm{NA}$ & cotomy+exc & AVM nidus & $\begin{array}{l}\text { sig improvement } \\
\text { Post-SRS AVM obliteration } 44 \text { month }\end{array}$ \\
\hline 13 & $\begin{array}{l}\text { Buis }^{22} \\
2010 \text { May }\end{array}$ & $1 / 15$ & $-/ F$ & & R temporal AVM & $\begin{array}{l}\text { LINAC } \\
18 \mathrm{~Gy}\end{array}$ & asym & 47 months & & cyst resection & $\mathrm{NA}$ & uncomplicated \\
\hline 14 & $\begin{array}{l}\text { Present study } \\
2010\end{array}$ & $3 / 201$ & $36 / \mathrm{F}$ & $\begin{array}{l}\text { Sz. } \\
\text { mass } \\
\text { effect }\end{array}$ & $\begin{array}{l}\text { 2:supratentorial } \\
\text { 1:vermis } \\
8.9 \mathrm{~cm}^{3}\end{array}$ & $\begin{array}{c}\text { LINAC/19 } \\
\text { Gy }\end{array}$ & $\begin{array}{l}\text { 1:asym } \\
\text { 2:high ICP }\end{array}$ & 11 years & $13.6 \mathrm{~cm}^{3}$ & $\begin{array}{l}\text { 1:Obs } \\
\text { 2:marsupialization }\end{array}$ & gliosis & Excellent \\
\hline
\end{tabular}

A/S: Age/Sex, Aspir:Aspiration, Asym:Asymptomatic, CPS:CystoPeritoneal Shunt, C/T:Number of patients with cyst/Total number of patients, Exc:Excision, H/A: Headache, HCP:Hydrocephalus, Hge:Hemorrhage, ICP:IntraCranial Pressure, LINAC: Linear Accelerator, Lt:Left, Mx:Management, -:Not Available, Obs:Observation, Sx:Surgery, SRSx:Stereotactci RadioSurgery, sz:Seizure. Mean values.

patients undergoing SRS for AVM. In our patients, for instances, the dose ranged from 14 to $25 \mathrm{~Gy}$.

\section{MANAGEMENT}

Patients with incidentally discovered cysts can be safely managed conservatively. There is no consensus regarding the optimal timing or frequency for the follow up MRI after the AVM is obliterated. Pollock et al recommend that patients without symptoms undergo MRI evaluations every four to five years. Patients who develop subacute or late radiation reactions undergo follow-up imaging more frequently ${ }^{18}$.
The main indication for surgery is a symptomatic cyst with the presence of mass effect. Surgical treatment depends on imaging findings, cyst characteristics and surgeon experience. The surgical options are simple stereotactic cyst aspiration, stereotactic cyst aspiration and placement of an Omaya reservoir, placement of a cystoperitoneal shunt (CPS) or cyst excision/marsupialisation.

Stereotactic aspiration of the cyst contents can improve symptoms and might eliminate the cyst or significantly reduce the cyst volume. The main disadvantage is cyst recurrence. Pollock et al found that simple stereotactic aspiration of the cyst 
Table 3: Literature estimates on the incidence of delayed cyst formation

\begin{tabular}{l|l|l}
\hline Authors & $\begin{array}{l}\text { Total no. of AVM } \\
\text { patients }\end{array}$ & $\begin{array}{l}\text { No. of delayed cyst } \\
\text { Formation (incidence) }\end{array}$ \\
\hline Forster $^{10}$ & 1400 & $3(0.2 \%)$ \\
\hline Tanaka et al $^{13}$ & 400 & $2(<0.5)$ \\
\hline Kihlstrohm et al $^{14}$ & 1600 & $5(0.3 \%)$ \\
\hline Pan et al & 1203 & $20(1.6 \%)$ \\
\hline Yamamoto et al $^{26}$ & 38 & $3(7.9 \%)$ \\
\hline Nakamura et al & 27 & $6(2.8 \%)$ \\
\hline Present study & 2013 & $3(1.5 \%)$ \\
\hline
\end{tabular}

was ineffective as every cyst recurred within weeks of the operation $^{18}$. All patients eventually underwent CPS placement.

Stereotactic cyst aspiration and placement of an Ommaya reservoir was performed in a patient with a large cyst that developed 11 months after radiosurgical treatment of a parietal $\mathrm{AVM}^{16}$ but no outcome data was provided.

Placement of a CPS, either at the initial operation or after previous cyst aspiration has proved unsuccessful in alleviating symptoms, has provided a durable means to eliminate the mass effect in most patients ${ }^{18}$.

Multicystic or deep cysts are more difficult to safely place a catheter to that will treat all components of the lesion(s $)^{18}$. In these challenging cases direct surgical excision of the lesion may be the better option.

Izawa et al used neuroendoscopically-guided cyst fenestration and cysto-peritoneal shunting in two patients, and endoscopic cyst revision plus open microsurgical cyst fenestration and excision of the obliterated nidus in five patients. They found the endoscope to be a helpful aid in identification of the mural nodule and evaluation of cyst patency ${ }^{20}$.

A surgical option when the cyst abuts the cortical surface is cyst marsupialization wherein the part of the cyst wall adjacent to the surface is opened, its contents emptied, and the free cyst wall excised or sutured to the pericyst gliotic tissue. This enables a permanent conduit between the cyst and the surrounding arachnoid space. Marsupialization is safe, simple and, judging from our first case, appears to provide satisfactory long term results.

\section{OuTCOME}

The clinical outcome of patients who either have no or mild symptoms or of those who undergo a surgical procedure is generally good with most symptoms improving after surgery ${ }^{28-30}$. Our cases 1 and 3 had a good outcome in terms of both motor function and a significant reduction in daily seizure rate.

\section{Conclusion}

All radiosurgically treated AVM patients have a small but inherent risk of cyst formation. Prolonged follow-up in the form of MRI is important to detect this rare SRS-related complication. The optimal duration of follow-up of these patients is unknown with certainty but should depend on the clinico-radiological features and discretion of the treating physician. When indicated, the surgical management of these cysts should be individualized.
Clinical findings, location and morphology of the cyst will help to decide on the optimal treatment.

\section{ACKNOWLEDGEMENT}

The authors thank Dr. Marie-Christine Guiot, Department of Neuropathology, Montreal Neurological Hospital and Institute for her help during the preparation of the pathology slides.

\section{REFERENCES}

1. Jagannathan J, Petit J, Balsara K, Hudes R, Chin L. Long-term survival after gamma knife radiosurgery for primary and metastatic brain tumors. Am J Clin Oncol. 2004; 27:441-4.

2. Kimura T, Sako K, Tohyama Y, et al. Diagnosis and treatment of progressive space-occupying radiation necrosis following stereotactic radiosurgery for brain metastasis: value of proton magnetic resonance spectroscopy. Acta Neurochir (Wien). 2003; 145:557-64.

3. Okun MS, Stover NP, Subramanian T, et al: Complications of gamma knife surgery for Parkinson disease. Arch Neurol. 2001; 58:1995-2002.

4. Plowman P. Stereotactic radiosurgery VIII. The classification of postradiation reactions. Br J Neurosurg. 1999; 13:256-64.

5. Shenouda G, Souhami L, Podgorsak EB, et al. Radiosurgery and accelerated radiotherapy for patients with glioblastoma. Can $\mathbf{J}$ Neurol Sci. 1997; 24:110-15.

6. Statham P, Macpherson P, Johnston R, Forster DM, Adams JH, Todd NV. Cerebral radiation necrosis complicating stereotactic radiosurgery for arterovenous malformation. J Neurol Neurosurg Psychiatry. 1990; 53:476-9.

7. Takenaka N, Imanishi T, Sasaki H, et al. Delayed radiation necrosis with extensive brain edema after gamma knife radiosurgery for multiple cerebral cavernous malformations. Case report. Neurol Med Chir (Tokyo). 2003; 43:391-5.

8. Tandon N, Vollmer DG, New PZ, et al. Fulminant radiation-induced necrosis after stereotactic radiation therapy to the posterior fossa. Case report and review of the literature. J Neurosurg. 2001; 95:507-12.

9. Feindel W, Yamamoto YL, Hodge CP. Intracarotid fluorescein angiography. A new method for examination of the epicerebral circulation in man. Can Med Assoc J. 1967; 96:1-7.

10. Forster DMC. Complication management. Presented at the 2 nd Annual Congress of the International Stereotactic Radiosurgery Society. Boston, June 14-17, 1995.

11. Lindquist $C$. Complication management. Presented at the 2 nd Congress of the International Stereotactic Radiosurgery Society. Boston, Mass, 1995

12. Yamamoto M, Jimbo M, Hara M, Saito I, Mori K. Gamma knife radiosurgery for arteriovenous malformations: Long-term follow-up results focusing on complications occurring more than 5 years after irradiation. Neurosurgery. 1996; 38:906-14.

13. Tanaka T. two cases of cyst formation after Gamma knife radiosurgery for AVM. Presented at the 5th International Workshop on Cerebrovascular surgery. Fukuoka, Japan. 1997, 3-5.

14. Kihlström L, Guo W, Karlsson B, Lindquist C, Lindqvist M. Magnetic resonance imaging of obliterated arteriovenous malformations up to 23 years after radiosurgery. J Neurosurg. 1997; 86:589-93.

15. Radanowicz-Harttmann V, Bachli H, Gratzl O. Late complication of radiosurgery of AVMs with the gamma knife: A case report. Acta Neurochir (Wien). 1998; 140:194-5.

16. Kim MS, Lee SI, Sim JH. A case of very large cyst formation with Gamma Knife radiosurgery for an arteriovenous malformation. Stereotact Funct Neurosurg.1999; 72[Suppl 1]:168-74.

17. Flickinger JC, Kondziloka D, Lunsford LD, et al. A multipleinstitutional analysis of complication and outcomes after arteriovenous malformation radiosurgery. Int $\mathbf{J}$ Radiat Oncol Biol Phys. 1999; 44:67-74. 
18. Pollock B, Brown R. Management of cysts arising after radiosurgery to treat intracranial arteriovenous malformations. Neurosurgery. 2001 August; Vol. 49, No. 2:259-65.

19. Pan H, Sheehan J, Stroila M, Steiner M, Steiner L. Late cyst formation following gamma knife surgery of arteriovenous malformations. J Neurosurg. 2005 Jan;102 Suppl:124-7.

20. Izawa $\mathbf{M}$, Chernov $\mathbf{M}$, Hayashi $\mathbf{M}$, et al. Management and prognosis of cysts developed on long-term follow-up after Gamma Knife radiosurgery for intracranial arteriovenous malformations. Surg Neurol. 2007 Oct; 68(4):400-6.

21. Wolak ML, Murphy EC, Powell SZ. Tumefactive cyst with a vascular blush as a late complication after combined embolization and stereotactic radiosurgery treatments for a cerebral arteriovenous malformation. Acta Neurochir (Wien). 2007; 149(7):705-12.

22. Buis DR, Meijer OW, van den Berg R, et al. Clinical outcome after repeated radiosurgery for brain arteriovenous malformations. Radiother Oncol. 2010 May; 95(2):250-6.

23. Izawa $\mathbf{M}$, Hayashi $\mathbf{M}$, Chernov $\mathbf{M}$, et al. Long-term complications after gamma knife surgery for arteriovenous malformations. J Neurosurg. 2005; Suppl 102:34-7.

24. Schlienger M, Atlan D, Lefkopoulos D, et al. Linac radiosurgery for cerebral arteriovenous malformations: results in 169 patients. Int J Radiat Oncol Biol Phys. 2000; 46:1135-42.
25. Yamamoto M, Hara M, Ide M, Ono Y, Jimbo M, Saito I. Radiationrelated adverse effects observed on neuro-imaging several years after radiosurgery for cerebral arteriovenous malformations. Surg Neurol. 1998; 49:385-98.

26. Yamamoto $M$, Ide $M$, Jimbo M, Hamazaki M, Ban S. Late cyst convolution after gamma knife radiosurgery for cerebral arteriovenous malformations. Stereotact Funct Neurosurg. 1998 Oct;70 Suppl 1:166-78

27. Nakamura H, Boku N, Jokura H, Takahashi Y, Yoshimoto T. Intracerebral cyst formation following stereotactic radiosurgery for AVM: Report of six cases. Presented at the 6th Annual Meeting of the Japanese Society of Stereotactic Radiosurgery. Nagoya, July 26, 1997.

28. Hara M, Nakamura M, Shiokawa Y, et al. Delayed cyst formation after radiosurgery for cerebral arteriovenous malformations: Two case reports. Minim Invasive Neurosurg. 1998; 41:40-5.

29. Elwell V, Koo $\mathrm{Ng} \mathrm{N}$, Dhanjal M, Peterson D. Cerebral cyst formation in pregnancy following gamma knife surgery of an underlying arteriovenous malformation. Br J Neurosurg. 2008 Dec; 22(6):808-9.

30. Pollock BE, Gorman DA, Coffey RJ. Patient outcomes after arteriovenous malformation radiosurgical management: results based on a 5- to 14-year follow-up study. Neurosurgery. 2003 Jun; 52(6):1291-6. 